\title{
Consensus on melanonychia nail plate dermoscopy ${ }^{*}$ Consenso sobre dermatoscopia da placa ungueal em melanoniquias
}

\author{
Nilton Di Chiacchio ${ }^{1}$ \\ Sergio Henrique Hirata ${ }^{4}$ \\ Ralph Daniel $^{7}$ \\ Beth S Ruben ${ }^{9}$ \\ Eckart Haneke ${ }^{12}$ \\ Richard Scher ${ }^{15}$
}

\author{
Débora Cadore de Farias ${ }^{2}$ \\ Bertrand Richert ${ }^{5}$ \\ Pier Alessandro Fanti ${ }^{3}$ \\ Philip Fleckman ${ }^{10}$ \\ Patricia Chang ${ }^{13}$ \\ Antonella Tosti ${ }^{16}$
}

\author{
Bianca Maria Piraccini ${ }^{3}$ \\ Martin Zaiac ${ }^{6}$ \\ Josette Andre ${ }^{8}$ \\ Phoebe Rich ${ }^{11}$ \\ Judith Dominguez Cherit ${ }^{14}$
}

\begin{abstract}
This statement, focused on melanonychia and nail plate dermoscopy, is intended to guide medical professionals working with melanonychia and to assist choosing appropriate management for melanonychia patients. The International Study Group on Melanonychia was founded in 2007 and currently has 30 members, including nail experts and dermatopathologists with special expertise in nails. The need for common definitions of nail plate dermoscopy was addressed during the Second Meeting of this Group held in February 2008. Prior to this meeting and to date (2010) there have been no evidence-based guidelines on the use of dermoscopy in the management of nail pigmentation.
\end{abstract}

Keywords: Dermoscopy; Melanoma; Nails; Nail diseases

Resumo: Este consenso, com foco em melanoníquia e dermatoscopia da lâmina ungueal, se destina a orientar os médicos que trabalham com melanoníquia e auxiliar no manejo destes pacientes. O grupo internacional de estudos sobre melanoníquia foi fundada em 2007 e tem agora 30 membros, incluindo dermatologistas e dermatopatologistas com conhecimento especializado em unhas. A necessidade de definições comuns de dermatoscopia da lâmina ungueal foi abordada durante a segunda reunião deste grupo, realizada em fevereiro de 2008. Antes desta reunião e até a presente, não existem orientações com base em evidências sobre a utilização de dermatoscopia da placa ungueal.

Palavras-chave: Dermoscopia; Doenças da unha; Melanoma; Unhas

Received on 05.04.2012.

Approved by the Advisory Board and accepted for publication on 15.06.2012.

* Paper produced by the International Study Group Meeting on Melanonychia (2010) - Miami, USA.

Conflict of interest: None

Financial funding: None

MD - Dermatology Clinic, Hospital do Servidor Público Municipal de São Paulo - São Paulo (SP), Brazil.

MD - Dermatology Clinic, University Hospital, Federal University of Santa Catarina (HU-UFSC) - Florianópolis (SC) - Brazil.

MD - Department of Dermatology, University of Bologna (UNIBO) - Bologna, Italy.

MD - Department of Dermatology, Federal University of São Paulo (UNIFESP) - São Paulo (SP), Brazil.

MD - Dermatology Department, University of Liège (ULg) - Liège, Belgium.

MD - Greater Miami Skin and Laser Center - Miami, USA.

MD - Department of Dermatology, University of Mississippi; Department of Dermatology, University of Alabama (UA) - Birmingham, USA

MD - Department of Dermatology, Université Libre de Bruxelles (ULB) - Brussels, Belgium.

MD - Departments of Dermatology and Pathology, University of California - California, USA.

MD - Division of Dermatology, University of Washington - Washington, DC USA.

MD - Department of Dermatology, University of Oregon - Oregon, USA.

MD - Dermatology Practice, Freiburg (Germany) and Dermatology Department, University of Berne - Berne, Switzerland.

MD - Department of Dermatology, Hospital Angeles - Mexico City, Mexico.

MD - Department of Dermatology, Hospital General "Dr Manuel Gea González" - Mexico City, México.

MD - Department of Dermatology, University of North Carolina - Chapel Hill, USA

MD - Department of Dermatology, Miller Medical School, University of Miami - Coral Gables, USA.

(C)2013 by Anais Brasileiros de Dermatologia 
This statement, focused on melanonychia and nail plate dermoscopy, is intended to guide medical professionals working with melanonychia and to assist choosing appropriate management for melanonychia patients.

The International Study Group on Melanonychia was founded in 2007 by Professor Antonella Tosti and Professor Nilton Di Chiacchio. The Group includes nail experts and dermatopathologists with expertise in nails from twelve different countries.

Prior to this meeting and to date there have been no evidence-based guidelines on the use of dermoscopy in the management of nail pigmentation.

16 members of the International Study Group on Melanonychia participated in this study.

A detailed literature search on nail dermoscopy, nail pigmentation and melanonychia including Medline, Embase, Cochrane and a hand search were carried out ${ }^{(1-10)}$. Based on the available literature, the Group decided to develop an informal consensus process at S1 level.

The Group reviewed publications on melanonychia and nail plate dermoscopy (Pub med indexed or not), approved by the American Academy of Dermatology, Miami, 2010 (Table 1).

This clinical consensus statement proposes consideration of a number of important points. About the technique used for nail dermoscopy, devices, polarized and non- polarized that can be used for nail plate dermoscopy. No evidence or consensus exists on which instrument and what kind of light source is the most effective. The color and definition of the lines may vary among the different devices. The group suggests using the same device in the follow-up evaluation of the patient, with magnification of 10X (the best). This allows the whole nail plate to be seen in the field, as well as the regularity of lines to be evaluated. The best immersion fluid for the nail plate is ultrasound gel.

According to the patterns found, the group agrees that nail plate dermoscopy is useful to distinguish blood from melanin. Subungual hemorrhages have a distinct pattern of globules, with or without distal streaks, with a range of color varying from red to brown to black (Figure 1A). The risk of coincidental bleeding from a subungual tumor must be taken into consideration. The dermoscopic diagnosis of subungual hematoma does not rule out a coincident nail tumor.

According to the literature, the pattern of benign melanonychia due to melanocyte activation (ethnic-type or drug-induced pigmentation) and lentigo exhibits a homogeneous gray coloration of the background with thin longitudinal gray lines. The group agrees that it is difficult to distinguish a light brown from a gray background and that a gray background is infrequently observed (Figure $1 \mathrm{~B}$ ). The color of the background is not a distinctive feature of benign lesions due to melanocyte activation. The color due to the melanin deposition may vary depending on the thickness of the nail and melanin location within the nail plate because of the "Tyndall" effect.

The brown background associated with regular parallel lines of identical color, spacing, and width suggests a benign lesion, either nevus or lentigo. The group agrees, even though this regular pattern is not often observed. Most benign lesions in children and adults show a brown background with longitudinal lines of different color and width. Line distribution within the band is most frequently irregular (Figure 1 C).

The brown background associated with longitudinal lines that are irregular in color, width, spacing, and parallelism is suggestive of malignant melanoma. The group agrees that benign nevi in children often show this pattern. Even in benign lesions of adults, individual lines may be irregular in width and color. The important point is the homogeneity of color and width of each individual longitudinal line. If an individual line shows irregularity in color or width along its length this is considered suspicious of melanoma. Melanoma in adults often shows a diffuse dark background with barely visible lines (Figure $1 \mathrm{D})$. The group agrees that a dark background with areas of different hue of pigmentation is suggestive of melanoma even in the absence of irregular lines.

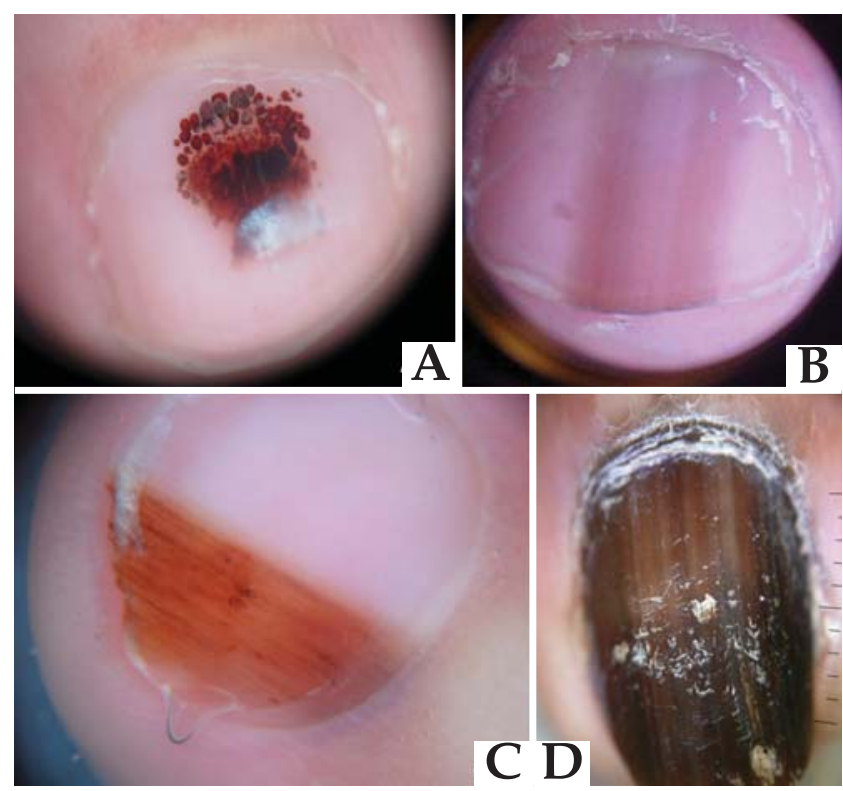

FIGURE 1: A - Subungual hemorrhages showing pattern of globules: B - Benign melanonychia due to melanocyte activation - difficult to distinguish a light brown from a gray background: C - Benign lesions in children (nevus) showing a brown background with longitudinal lines of different color and width: D - A melanoma with dark background with areas of different hue of pigmentation 
TABLE 1: Review of the literature

\begin{tabular}{|c|c|c|c|}
\hline First Author & $\begin{array}{l}\text { Number of } \\
\text { cases }\end{array}$ & Nail plate dermoscopy & Pathology \\
\hline $\begin{array}{l}\text { Imakado S, } \\
\text { et al }{ }^{6}\end{array}$ & 2 & $\begin{array}{l}\text { Dermoscopic examination of the site of Hutchinson's sign showed irre- } \\
\text { gular pigmentation on the ridge. Nail plate dermoscopy not described. }\end{array}$ & MM in situ \\
\hline $\begin{array}{l}\text { Gencoglan } \\
\mathrm{G}_{\text {, et }} \mathrm{al}^{3}\end{array}$ & 1 & $\begin{array}{l}\text { Homogeneous, brownish, regular bandlike pigmentations with indis- } \\
\text { tinct borders were seen on } 4 \text { toenails }\end{array}$ & LHS \\
\hline $\begin{array}{l}\text { Antonovich } \\
\mathrm{DD} \text {, et } \mathrm{al}^{7}\end{array}$ & 1 & $\begin{array}{l}\text { With dermoscopy the pigmentation was observed as streaky and irre- } \\
\text { gular. }\end{array}$ & MM in situ \\
\hline $\begin{array}{l}\text { Caseret AS, } \\
\text { et } \mathrm{al}^{4}\end{array}$ & 1 & $\begin{array}{l}\text { Homogeneous blue blotch and a regularly-pigmented grayish longitu- } \\
\text { dinal melanonychia }\end{array}$ & Blue nevus \\
\hline $\begin{array}{l}\text { Iorizzo M, } \\
\text { et } \mathrm{al}^{8}\end{array}$ & 2 & $\begin{array}{l}\text { C1: Dark brown to gray background with longitudinal and irregular } \\
\text { parallel lines. Edges appeared ill-defined } \\
\text { C2: No nail plate dermoscopy }\end{array}$ & MM in situ \\
\hline $\begin{array}{l}\text { Hirata SH, } \\
\text { et } \mathrm{al}^{5}\end{array}$ & 10 & $\begin{array}{l}\text { C1: Brown coloration of the background, brown-black regular lines } \\
\text { C2: Brown coloration of the background, regular lines } \\
\text { C3: Grayish and brown coloration of the background, regular lines } \\
\text { C4: Grayish and brown coloration of the background, regular lines } \\
\text { C5: Brown coloration of the background, brown-black regular lines } \\
\text { C6: Black coloration of the background } \\
\text { C7: Grayish and brown coloration of the background, regular lines } \\
\text { C8: Grayish and brown coloration of the background, regular lines } \\
\text { C9: Grayish and brown coloration of the background, regular lines } \\
\text { C10: Brown coloration of the background, black regular lines }\end{array}$ & $\begin{array}{l}\text { C1: TMH } \\
\text { C2: TMH } \\
\text { C3: TMH } \\
\text { C4: TMH } \\
\text { C5: JMN } \\
\text { C6:TMH } \\
\text { C7:CH } \\
\text { C8:CH } \\
\text { C9:CH } \\
\text { C10: OC }\end{array}$ \\
\hline
\end{tabular}

Hass $\mathrm{N}$ et $\mathrm{al}^{2}$

Kawabata Y, 24 et $\mathrm{al}^{11}$
18 individual pseudopods protruded along its longitudinal axis, up to $1.1 \mathrm{~mm}$ in length and $0.2 \mathrm{~mm}$ wide and of straight or twisted shape

6 MM: Initially longitudinal pigmented streaks in the nail plate which increased in breadth, finally involving the whole nail plate, without deformities. Hutchinson's sign was observed in all cases.

18 BMN: 15 showed partial pigmentation in the nail plate, and in 3 the entire nail plate was involved, without deformities. Pigmented macules of the fingertip were observed in the same 3 cases and another 2 cases.

However the surface profiles of the hyponychial pigmentation of subungual melanoma obtained by the dermoscope were different from those of BMN, although dermoscopic features of the nail plates are indistinguishable. The pattern of pigmentation of BMN had a brushy linear structure across the skin marks. In contrast, subungual melanoma in situ exhibited haphazard pigmentation distributed in a disorderly fashion over the entire surface.
Hemorrhage

$6 \mathrm{MM}$

$18 \mathrm{BMN}$ 
TABLE 1: Review of the literature

\begin{tabular}{lll}
\hline First Author & $\begin{array}{l}\text { Number of } \\
\text { cases }\end{array}$ & Nail plate dermoscopy \\
\hline $\begin{array}{l}\text { Ronger S, } \\
\text { et al 1 }\end{array}$ & 148 & $\begin{array}{l}\text { Melanoma (20 cases): association of brown pigmentation of the back- } \\
\text { ground }(19 / 20 ; 95 \%) \text { with longitudinal brown to black lines irregular } \\
\text { in their coloration, spacing, thickness and parallelism. The irregular } \\
\text { pattern of the lines was significantly associated with melanoma when } \\
\text { compared with all other diagnoses }(\mathrm{P}=.001 \text {, taken either individually or } \\
\text { as a group }(\mathrm{P}=.001 \text { in all } 5 \text { differential diagnoses). Melanoma shared } \\
\text { with melanocytic nevus the brown coloration of the background. }\end{array}$
\end{tabular}

Melanocytic nevus (37 cases): brown background (37/37; 100\%) and the regular pattern of the longitudinal lines $(35 / 37 ; 95 \%)$. The presence of these lines, regular in their thickness, spacing, coloration, and parallelism, was found statistically sufficient to distinguish nevus from melanoma ( $\mathrm{P}=.001)$.

Drug-induced nail pigmentation (16cases): grayish coloration of the background $(15 / 16 ; 94 \%)$ and the presence of thin longitudinal gray lines with regular thickness, spacing, coloration and absence of parallelism disruption. These dermoscopic findings were no different from the ones observed in ungual lentigo or ethnic-type pigmentation, but significantly differed from melanoma $(\mathrm{P}=.001)$.

Nail apparatus lentigo (45 cases): grayish coloration of the background $(44 / 45 ; 98 \%)$ and the presence of thin longitudinal gray lines, regular in their coloration, thickness and spacing $(42 / 45 ; 93 \%)$. The presence of these 2 criteria significantly differentiated nail lentigo from melanoma $(\mathrm{P}=.001)$.

Ethnic-type pigmentation (8 cases): The patterns in these cases were similar to those previously described in ungual lentigo and drug induced nail pigmentation, but significantly different from those of melanoma $(\mathrm{P}=.001)$. The two characteristic dermoscopic features of ethnictype nail pigmentation were the grayish background $(7 / 8 ; 87.5 \%)$ and the thin, regular gray lines $(7 / 8 ; 87.5 \%)$.

Subungual hemorrhage (22 cases): well-defined, rounded proximal edge and a purple to brown coloration were observed in all cases of subungual hemorrhages $(22 / 22 ; 100 \%)$.

Bilemjian 2

APJ, et al 10
C1: 1st right digit : Lateral side: A light and dark brown color pigmentation, distributed in a linear and parallel fashion throughout the nail from the cuticle to the free edge.

Medial part: A totally amorphous and irregular area, affecting the proximal nail fold - the micro-Huntchinson sign.

C2: 5th left digit: Brown parallel homogeneous longitudinal lines; regular in space, width and color.
Pathology

$20 \mathrm{MM}$

37BMN

16 DHNP

45 NAP

$8 \mathrm{ETP}$

$\mathrm{C} 1: \mathrm{MM}$ in situ

C2: $\mathrm{TMH}$
LHS: Laugier Hunziker Syndrome TMH: Typical melanocytic hyperplasia JMN: Junctional melanocytic nevus $\mathrm{CH}$ : Constitutional pigmentation (Hypermelanosis)
OC: Onychomycosis

BMN: Benign melanocytic nevi

DHNP: Drug-induced nail pigmentation

NAL: Nail apparatus lentigo
ETP:Ethnic type pigmentation

SH: Subungual hemorrhage

MM: Malignant Melanoma 
Other applications of dermoscopy at the nail apparatus are reported. Distal edge dermoscopy is helpful for identifying the origin of the pigment producing lesion (distal or proximal matrix). The group agrees that distal edge dermoscopy is not always useful, particularly when the nail plate is thin. The same applies to very dark or very light bands. Dermoscopy of the hyponychium allows to distinguish pigmentation due to melanocytic nevi characterized by linear pigmentation in the furrows or across the skin marks, from pigmentation associated with nail melanoma (Hutchinson's sign), where dermoscopy shows haphazard pigmentation distributed in a parallel ridge pattern in a disorderly fashion. ${ }^{11}$ The group agrees that dermoscopy of the hyponychium is useful in cases where melanonychia is associated with pigmentation of the hyponychium.

The group agrees that the nail plate dermoscopic patterns stated in the literature, as indicative of nail melanoma, need to be modified as follows:
- Brown bands with lines irregular in color, width and spacing are not indicative of melanoma in children;

- Benign lesions in adults can present with irregular lines and spacing; and

- Melanoma in adults is often present with a very dark background where the lines are difficult to see.

The group also agrees that at present any decision to excise should be based on established clinical criteria (history and physical exam) and not on nail plate dermoscopy patterns. Dermoscopy of the hyponychium is very useful for differential diagnosis between nevi and melanoma in the case of pigmentation of the periungual tissues.

\section{REFERENCES}

1. Ronger S, Touzet S, Ligeron C, Balme B, Villard AM, Barrut D, Collin C, Thomas L. Dermatoscopic examination of nail pigmentation. Arch Dermatol. 2002;138:132733.

2. Haas N, Henz BM. Pitfall in pigmentation: pseudopods in the nail plate. Dermatol Surg 2002;28:966-7

3. Gencoglan G, Gerceker-Turk B, Kilinc-Karaarslan I, Akalin T, Ozdemir F. Dermoscopic findings in Laugier-Hunziker syndrome. Arch Dermatol. 2007;143:631-633

4. Caseret AS, Skowron F, Viallard AM, Balme B, Thomas L. Subungual blue nevus. J Am Acad Dermatol. 2003;49:310-2.

5. Hirata SH, Yamada S, Almeida FA, Enokihara MY, Rosa IP, Enokihara MM, et al. Dermoscopic examination of the nail bed and matrix. Int J Dermatol. 2006;45:28-30.

6. Imakado S, Sato $\mathrm{H}$, Hamada $\mathrm{K}$. Two cases of subungueal melanoma in situ. J Dermatol. 2008;35:754-8.

7. Antonovich DD, Grin C, Grant-Kels JM. Childhood subungual melanoma in situ in diffuse nail melanosis beginning as expanding longitudinal melanonychia. Pediatr Dermatol. 2005;22:210-2.

8. Iorizzo M, Tosti A, Di Chiacchio N, Hirata SH, Misciali C, Michalany N, et al. Nail melanoma in children: differential diagnosis and management. Dermatol Clin. 2008;34:974-8.

9. Braun RP, Baran R, Saurat JH, Thomas L. Surgical Pearl: Dermoscopy of the free edge of the nail to determine the level of nail plate pigmentation and the location of its probable origin in the proximal or distal nail matrix. J Am Acad Dermatol. 2006;55:512-3
10. Bilemjian APJ, Maceira JP, Barcaui CB, Pereira FB. Melanoniquia: importância da avaliação dermatoscópica e da observação da matriz / leito ungueal. An Bras Dermatol. 2009;84:185-9.

11. Kawabata Y, Ohara K, Hino H, Tamaki K. Two kinds of Hutchinson's sign, benign and malignant. J Am Acad Dermatol. 2001;44:305-7.

How to cite this article: Di Chiacchio N, Cadore de Farias D, Piraccini BM, Hirata SH, Richert B, Zaiac M, Fanti PA, Andre J, Ruben BS, Fleckman P, Rich P, Haneke E, Chang P, Cherit JD, Scher R, Tosti A. Consensus on melanonychia nail plate dermoscopy. An Bras Dermatol. 2013;88(2):309-13. 